\title{
Selected Reference Books of 1969-70
}

\section{INTRODUCTION}

$\mathrm{T}$ HIS ARTICLE continues the semiannual series originally edited by Constance M. Winchell. Although it appears under a byline, the list is actually a project of the Reference Department of the Columbia University Libraries, and notes are signed with the initials of the individual staff members. ${ }^{1}$

Since the purpose of the list is to present a selection of recent scholarly and foreign works of interest to reference workers in university libraries, it does not pretend to be either well balanced or comprehensive. Code numbers (such as AA71, 1EA29) have been used to refer to titles in the Guide to Reference Books and its supplements. ${ }^{2}$

\section{Library Catalogs}

Chicago. Center for Research Libraries. Catalogue. Chicago: The Center, 1969. (In progress) Newspapers, 1v. (176 p.); Monographs, $5 v$. $\$ 211.50$ the set.

The Center for Research Libraries is an outstanding example of interlibrary cooperation, and publication of its catalog will not only make known its resources to member libraries, but will provide a useful bibliographic aid for research libraries in general. The complete catalog will comprise seven volumes in three sections: monographs, serials (including newspapers), and newspapers. Each section is available separately to enable libraries to purchase

${ }^{1}$ Rita Keckeissen, Georgia Lanzano, Eileen McIlvaine, Mary Ann Miller, Heidemarie Peterson, Janet Schneider, Nancy Schroeder; School of Library Service, Evelyn Lauer.

${ }^{2}$ Constance M. Winchell, Guide to Reference Books (8th ed.; Chicago: American Library Association, 1967 ); Supplement I (Chicago: ALA, 1968); Supplement II (Chicago: ALA, 1970). only those sections needed or to duplicate certain sections without purchasing full duplicate sets.

The newspaper catalog includes "all newspaper titles housed at and available through the Center . . . even though some of the titles, such as those included in the ARL Foreign Newspaper Microfilm Project, are not available to members of the Center unless they are also subscribers to that particular project."-Introd. Both original and microfilm holdings cataloged through 1968 are included. Listing is by title, but provision of cross-references under city of publication allows a very useful geographical approach.

Unfortunately the monograph catalog (a main entry listing) does not include certain important collections at the Center. Omitted are archival materials, children's books, Chinese books, various collections of state, federal, and foreign government documents, and-most disappointingly - the nearly 600,000 printed foreign dissertations on file at the Center.-E.S.

Deutsches Archäologisches Institut. Römische Abteilung. Bibliothek. Kataloge des Deutschen Archäologischen Instituts, Rom. Boston: G. K. Hall, 1969. Autoren- und Periodica Kataloge. 7v. \$555; Zeitschriften-Autorenkatalog. 3v. \$185.

Published in the now familiar format, this is the catalog of one of the world's strongest archaeological libraries. Founded in 1830, the library has grown to include some 91,000 volumes in all areas of European and Near Eastern archaeology and philology, from the prehistoric to the Byzantine period. One special strength is the Bibliotheca Platneriana-a collection of books on the history of Italian cities-donated to the library in 1879 .

The Autoren- und Periodica Kataloge contains reproductions of catalog cards representing main entries for monographs and periodical titles, the periodicals being 
listed separately in v.7, pages 563-816. Form of entry for journals does not conform to American practice; e.g., the American Journal of Archaeology is entered under "Journal American Archaeology." Another caution: alphabetizing is by keyword; $I$ and $J$ interfile. Of great use to librarians and scholars are the analytics for monographic sets provided under the name of the series.

Coverage of the Zeitschriften-Autorenkatalog begins with articles published in 1956 in periodicals, Festschriften, and other special publications. Articles indexed are limited to classical archaeology and epigraphy.

A Systematischer Katalog, available from the same publisher ( $3 \mathrm{v} ., \$ 330)$, is designed to categorize in some 1,200 subject areas the post-1955 works held by the library.-E.M.

\section{Printing}

Geldner, Ferdinand. Die deutschen Inkunabeldrucker; ein Handbuch der deutschen Buchdrucker des XV. Jahrhunderts nach Druckorten. Stuttgart: A. Hiersemann, 1968- . (In progress) v.1, Das deutsche Sprachgebiet. 310p. il. DM120.

Intended as an introduction for the researcher, for the librarian, the collector, the rare-book dealer, and for anyone who enjoys beautiful old books, this is the first volume of a work concerned with the German printers of the first century of printing. A geographical approach is used: from Mainz, the birthplace of printing, the growth and spread of the art throughout Europe is traced in chronological order. Volume I embraces the work of printers active in German-speaking areas; a second volume will portray the work of German printers in other European countries. For each entry we find the printer's biography and a description of his characteristic use of tools of the craft. Extensive footnote references offer good bibliographical coverage. The author emphasizes that in a work of this kind he could not attempt to settle controversies over the identification of anonymous works of the early printers. - H.P.

\section{National Bibliography}

Catalogue des livres disponibles: littérature et sciences humaines, 1969- . Paris: Cercle de la Librairie, 1969- . Annual? $90 \mathrm{~F}$.

The first reference work of its kind published in France, this is a catalog of French-language publications available in the booktrade. It corresponds to Books in Print, and is compiled from publishers' catalogs. This first edition is limited to the humanities and social sciences and is divided into three parts: (1) a main section in classified arrangement, (2) title index, and (3) author index. Only the entries in the classified section provide full information-author, title, series, pagination, price, edition, and publisher. The classified section is subdivided as "Litterature" and "Sciences Humaines," the former embracing belles lettres, philology, and literary criticism, while the latter stands for social sciences in the broadest sense, with philosophy, religion, and history included in this category. Within these two major sections there are further detailed breakdowns for specialized disciplines and subject fields, each with its class number. In the alphabetical author and title indexes these class numbers serve as the clue for finding the complete entry. A second Catalogue des livres disponibles is in preparation; it will embrace all subjects.-H.P.

Magyar könyvészet, 1945-1960; a Magyarországon nyomtatott könyvek szakositott jegyzéke. Budapest: [Országos Széchenyi Könyvtár] 1965-68. 5v.

Primarily a Hungarian national bibliography for the publications of the sixteen postwar years, this set also supposedly takes into account works that appeared from 1942 to 1944. (A search did not reveal any citations with imprint dates of these war years, but their seeming absence may be due to the chaos of that period rather than to editorial discretion.) In effect, it represents a cumulation of the 1945-60 annual volumes of Magyar nemzeti bibliográfia (Guide AA540), with the addition of coverage for 1945. It is a classed listing, using UDC, with cross-ref- 
erences from all categories under which a citation might fit. Series and anthologies are analyzed for contents-a real bonus for verification-and each volume has its own subject index to the categories therein. Volume 5, which includes addenda, is an index to the preceding volumes and lists authors, editors, compilers, institutes, and proper nouns in titles; many titles are indexed, but not those for belles-lettres. Bibliographically the work ranks with the best of its kind for clarity and detail; it also offers a good typographical quality characterized by sharp print, varying type sizes, and generous spacing between citations.-E.L.

Shipton, Clifford K., and Mooney, James E. National Index of American Imprints through 1800; the Short-title Evans. [Worcester, Mass.]: American Antiquarian Society and Barre Publishers, 1969. 2v. (1028p.) \$45. (69-11248).

Although this list is a by-product of and an index to the Readex Microprint edition of Early American Imprints, it can stand as an independent work because it includes many valuable corrections and revisions of entries in Charles Evans' American Bibliography (Guide AA333). It is an author (or anonymous title) list of works cited in Evans and in Roger Bristol's supplement thereto (Guide AA333a), giving an abbreviated title, place and date, pagination, location of the specific copy photocopied for the microprint series, and the Evans number.

Bibliographically the work's value will be for its revisions of Evans' often erroneous entries. Authors listed by Evans were carefully checked so that those with similar names but different dates have been identified and listed separately. There are title entries for works of assumed authorship. Evans items that could not be located or positively identified are included in brackets, with an explanatory note indicating probable or suggested origin of the entry. Each item was checked to insure that it is a separate work, and that the bibliographic information is correct. For libraries owning the microprint series this is a virtually indispensable aid (especially for the Bristol additions), but in other li- braries it will be a useful complement to Evans.-G.L.

\section{LIBRARIANSHIP}

Danton, J. Periam. Index to Festschriften in Librarianship. New York: Bowker, 1970. 461p. \$13.50. (75-88796).

Compiled by a librarian for the use of others interested in librarianship, this work can serve as a model of completeness and organization for any similar compilation. "The main body of the work is a single alphabetical author and subject index, with cross-references, to articles on libraries and closely related topics-publishing, printing, reading, etc.-appearing in Festschriften honoring librarians, libraries, and library associations. Editors and joint editors of the volumes are also included."-Guide to the User. Altogether there are citations for 3,300 articles in 283 publications from twenty-two countries in sixteen languages, published between 1864 and 1966. Festschriften that appeared as special issues of journals are included, but not anniversary library histories. Occasional individual articles that have nothing to do with librarianship are not indexed. Subject headings are generously assigned, with some articles having as many as eight; many headings have "see also" references to give the user complete access to all possible citations. Added features of the work are citations to reviews of the Festschriften, biographical references for the honorees, and two tables: one for the number of Festschriften by country of origin and another for the number by date of publication. Scholars in this field will be delighted with this well-planned key to the often elusive contents of homage volumes.-E.L.

\section{Government Publications}

Congressional Information Service. Index to Publications of the United States Congress, v.1, no.1- , 1970- . [Washington, 1970- .] Monthly, with annual bound cumulation in $2 \mathrm{v}$. Priced according to library budget.

Cover title: CIS Index.

This new indexing service abstracts con- 
gressional committee hearings and prints, House and Senate reports, documents and miscellaneous publications, and Senate executive reports and documents, with the aim of being "a master index to the contents of Congressional publications."-Introd. Arrangement is in two parts: (1) the "Summary Section," which lists the abstracts by committee, with publications issued by the House and Senate as a whole in separate categories; and (2) the "Index Section," which has a full index of subjects, authors, witnesses, subcommittees, popular names of laws, reports and bills. Four other indexes are lists of bills, reports, and documents, each by number, and an index of committee and subcommittee chairmen. Indexes are to cumulate quarterly. The Introduction gives detailed instructions for use. If the publisher maintains his schedule of publishing the index for one month's documents early in the following month, the work should prove useful to the student, the research worker, and the librarian.-R.K.

\section{BIOGRAPHY}

Dictionary of South African Biography. W. J. de Kock, ed.-in-chief. [Cape Town]: Publ. for the National Council for Social Research, Dept. of Higher Education by Nasionale Boekhandel Bpk., [1968- ]. v.1- . (v.1, R. 8.00). (67-29090).

Planned and in progress for many years, this volume marks a seemingly auspicious beginning for a major new biographical dictionary. (Eric Rosenthal's one-volume Southern African Dictionary of National Biography, Suppl. 1AJ3, is virtually the only predecessor for this area.) The work is designed to present "the life histories of all those who have since the earliest European contact with the southern extremity of Africa made a contribution of importance to the course of South African history."-Introd. Thus, various personalities to be included may never (or only briefly) have visited South Africa, though their political policies or other activities exerted significant influence on South African events. Rather than the familiar alphabetical or chronological arrangements, the editors have chosen to present whatever sketches are available as each volume is prepared for press. Individual volumes will be alphabetically arranged, and the second and all succeeding volumes will include cumulated indexes of names. The initial series will include 2,500 to 3,000 personalities who died before the end of 1950 , with supplementary volumes planned for successive decades. Among the 568 biographies in this first volume there is a good representation of tribal chieftains and native figures along with numerous missionaries, colonial personalities, and the expected political and military leaders. Articles of substantial, but varied length (Olive Schreiner, three pages; J. C. Smuts, twenty-one pages) are signed with the initials of contributors. In addition to a bibliography for each article there are usually some notes on iconography.-E.S.

New York Times Obituaries Index, 18581968. New York: New York Times, 1970. 1136p. \$45. (72-113422).

Countless hours of searching for death dates and obituary notices will be saved by this new publication. "It brings together, in a single alphabetical listing, all the names entered under the heading 'Deaths' in the issues of the New York Times Index from September 1858 through December 1968, augmented by entries for the years 1907 through 1912 (for which Indexes are still in preparation) and by names from the period 1913 through 1925, not listed in the published Indexes - a total of over 353,000 names."-Introd. Because editorial policy in the indexing of obituaries has varied over the years (e.g., accidental deaths, suicides, and various "front page" accounts were not always included in the "Deaths" listings), there are inconsistencies and surprising omissions of some prominent names. A fuller note on these inconsistencies would have been welcome. Notices of persons with identical names are indexed chronologically, with no attempt to distinguish them by a descriptive term. References to funerals and estate accountings are frequently included. This promises to be a highly valuable work, frequently useful in situations where actual consultation of the Times obituary is not essential.-E.S. 
Who's Who of British Scientists, 1969/ 70- . [London]: Longman, [1970]. Ed.1- . Annual? (v.1, 974p.) $£ 15$.

Because of rising production costs the Directory of British Scientists (Guide EA186) has had to discontinue publicationat least for the present-after the third edition. This new, one-volume work is admittedly only a partial substitute. It concentrates on "giving details of the background and careers of the 'top 10,000' of British men and women who are working in the Biological and Physical Sciences or who are enjoying careers of distinction after basic training in a scientific discipline."-Introd. Information was derived from questionnaires completed by the biographees.-E.S.

\section{LiNGUisTics}

Murphy, John D., and Goff, Harry. A Bibliography of African Languages and Linguistics. Washington, D.C.: Catholic Univ. of America Press, 1969. 147p. $\$ 4.95$ pa. (71-98990).

Over two hundred African languages are represented in this international bibliography, including varieties of Arabic, Hamitic, Malagasy, Afrikaans, and Creoles, as well as the "Negro African" dialects. The majority of the 1,218 monographs listed are items pertaining to the indigenous languages south of the Sahara. A general section consisting of entries for bibliography, press, general studies, regional studies, cartography, phonology and orthography, language-learning and languages in education precedes the chapters on non-Bantu languages of Northeastern Africa, non-Bantu languages of West Africa, Bantu languages, Malagasy, Afrikaans, and Creoles. Unfortunately, within each of the major sections no apparent arrangement-alphabetical or chronologicalhas been followed. Thus the language/ dialect and the author/compiler indexes are necessary approaches. Names of countries appear in the subject index only if part of a title. Although the compilers examined each work in the bibliography, they neglected to include pagination in the bibliographic citations. This data would have increased the usefulness of the tool for both librarians and researchers.J.S.

\section{Literature}

First-line Index of English Poetry, 15001800, in Manuscripts of the Bodleian Library, Oxford. Margaret Crum, ed. Oxford: Clarendon Press, 1969. 2v. 1257p. \&11, 5s. (72-397656).

In 1932 the task of indexing first lines of the English verse in Bodleian manuscripts began, inspired and urged on by Dr. Percy Simpson who saw that, in spite of extensive descriptive catalogs, "this material would remain virtually buried until an index of first lines could be provided."Pref. A card index was completed early in 1961 , and poetry in manuscripts acquired after that date is not included in the published index.

The alphabetically arranged entries have the following features: first line of the poem in modernized spelling, with variant wordings given in brackets; the usual version of the last line; author's name, title of the poem, and other information from the manuscript; references to printed versions of the poem; and indication of Bodleian manuscripts in which the poem is found. There are five important indexes: (1) Bodleian manuscripts listed by shelfmarks; (2) authors; (3) names mentioned in the poems; (4) authors of works translated, paraphrased or imitated; and (5) references to composers of settings and to tunes named or quoted. (This last index, coupled with the shelf-marks "Mus." and "Mus.Sch." in the first-line entries ought to open new vistas for the student of Renaissance music.)

A single reservation about this impressive index: failure to include an indication of a poem's line-count. Wouldn't it be helpful to the scholar to know whether a poem has two or two hundred lines? All in all, however, Miss Crum can be proud of her contribution to scholarship in having seen this monumental work through its long years of preparation.-M.M.

The New Cambridge Bibliography of En- 
glish Literature. George Watson, ed. Cambridge, [Eng.]: University Press, 1969- . (In progress) (69-10199). v.

3, 1800-1900. 1948 cols., plus index. $\& 10$.

Partly because the study of Victorian literature has advanced more rapidly and undergone greater changes than that of most other periods, the volume for the nineteenth century was given priority in this reworking of the Cambridge Bibliography of English Literature (Guide BD309). Basic design of the work remains the same and the task of the more than fifty contributors to this first-published volume "has been to revise and integrate the existing lists of 1940 and 1957, to add materials of the past ten years, to correct and refine the bibliographical details already available, and to reshape the whole according to the new conventions which have been designed to give the Bibliography a clearer and more consistent air."-Pref. Various nonliterary sections (such as those for political and social background, science, and law) have been omitted as impractical to update, but those for travel, sport, education, and the press have been retained and revised. Sections on the literatures of certain Commonwealth nations (Anglo-Indian, Canadian, South African, Australian and New Zealand) have been dropped. Individual author listings are now confined to "literary authors native to or mainly resident in the British Isles"; the scope of the listings themselves is largely unchanged. Editors were encouraged to drop outdated or superseded references, but since the history of an author's reputation is a recognized area of study, "articles which represent it memorably have been retained, even where they may have been discredited by later scholarship."Pref.

Period divisions for forthcoming volumes will remain the same, with a new, separate volume now in preparation for the "Earlier twentieth century (1900-1950)"; v. 5 will be a detailed index. Provisional indexes giving names of primary authors and selected subject categories will appear in each volume as published. Although it perpetuates certain shortcomings (as well as the many virtues) of the earlier edition, the NCBEL is to be warmly welcomed by scholars, students, and librarians. Most of us will want to retain the earlier edition in the reference collection even after the new work is complete.-E.S.

Richardson. Kenneth Riddley, ed. Twentieth Century Writing; a Reader's Guide to Contemporary Literature. London: Newnes, [1969]. 751p. 63s. (70-431735).

Designed as a guide for the general reader, this work includes information on the major works (novels, plays, collections of poems and short stories) of some 1,200 authors who lived and wrote at least one decade into the twentieth century and published a substantial amount after 1900 . Two-thirds of the material is devoted to English-language writers. Foreign-language writings are limited to European languages, and the availability of English translations was a criterion for inclusion. The scope of the work reflects the interests of the general reader: authors of science fiction and murder mysteries are found with writers of more serious literature. Arrangement is alphabetical by author, with a title index and an index by country. Coverage is superficial; biographical and bibliographical material is sparse. Longer articles usually include a complete listing of the author's books, while shorter entries list only those the contributor of the sketch considered most important or most popular. The book fulfills its aim as an introductory guide for the general reader, but it is of little interest to the scholar.J.S.

Rubin, Louis Decimus, ed. A Bibliographical Guide to the Study of Southern Literature. With an appendix containing sixty-eight additional writers of the colonial South by J. A. Leo Lemay. Baton Rouge: Louisiana State Univ. Press, [1969]. 351p. \$10. (69-17627).

Professor Rubin has "brought together compilations of some of the principal scholarship concerned with a number of the South's writers and some of the more pervasive themes and areas of investigation having to do with Southern literature."- 
Introd. $\mathrm{He}$ has interpreted "the South's writers" broadly, including anyone who was brought up or lived in the South, even those of minor significance. So, besides William Faulkner, Edgar Allan Poe and Thomas Jefferson, we find John Barth (raised in Maryland), Lafcadio Hearn (lived in New Orleans for thirteen years), and Mrs. E. D. E. N. Southworth (popular novelist of the $1850 \mathrm{~s}$ and 1860s). One could quibble and wish for inclusion of others, such as Arna Bontemps and Hinton Rowan Helper.

Arrangement of the bibliography facilitates its use. The first part contains bibliographical lists of important works on various periods, themes, and genres of Southern literature; the second part is an alphabetical list of some 140 authors, with citations to important critical and biographical works. For each author, theme, or period a scholar very knowledgeable about the topic was chosen to compile that particular bibliography - thus we have Louis B. Wright writing on William Byrd, Louis D. Rubin on James Agee, and Daniel Patterson on Southern folklore. The appendix includes colonial authors about whom little has been written, e.g., John Lawson, Richard Henry Lee, William Strachey. For many of them Professor Lemay has indicated areas for needed research.

Although designed for "the student who would begin work in the field of Southern literary study" (Introd.), this bibliographical guide, due to its thoroughness, can be used by graduate students and scholars in many areas of American literature.E.M.

Verzeichnis der schriftlichen Nachlässe in deutschen Archiven und Bibliotheken. Boppard: Harald Boldt Verlag, [19691. (In progress) Bd.2, Die Nachlässe in den Bibliotheken der Bundesrepublik Deutschlands, von Ludwig Denecke. 268p. DM 60.

The first published volume of a new series, this catalog of literary remains in West German libraries serves as a guide to source material which is usually hard to find. It includes references to a variety of literary documents in all subject fields: correspondence, diaries, travel notes, lectures, autographs, drawings, musical scores, programs, posters, photographs, reviews, observations of scientific experiments, etc. Listing is alphabetical by personal name; for each entry the collection is briefly characterized as to subject and form, and the manner of storing is indicated (e.g., folders, boxes, packages). Mention is made of collections lost or missing owing to wartime destruction. The work does not attempt detailed description; for this the researcher must write to or visit the repository. There is an index of the libraries and institutes represented, together with full citation to printed catalogs of pertinent collections. The editor states that similar compilations are in preparation for Switzerland, Austria, the German Democratic Republic, and Poland. Such diligence in listing these collections should throw light on and make accessible much obscure, fragmentary and elusive, but often valuable research material.-H.P.

\section{Drama and Theater}

Gassner, John, and Quinn, Edward, eds. The Reader's Encyclopedia of World Drama. New York: Crowell, [1969]. 1030p. il. \$15. (69-11830).

This is a work ambitiously conceived and imperfectly executed. Its scope is universal but its coverage is superficial in most areas outside Western Europe and North America. Of its 102 contributors, eighty are from the United States, and thirty-three of these from New York State; Europe is scantily represented by only ten contributors; the Middle East and Asia share four. One can allow that writers on a given national literature need not be of that nation, but further comparison shows imbalance in cultural coverage by depth of article, with noticeably greater space devoted to European and American figures and traditions.

Cultural bias aside, the work is, on the whole, readable on the high school or college level and does attempt to provide some suggestions for further reading by means of brief bibliographies. The subject of the work is drama as literature, not theatre; thus, there are no entries for ac- 
tors, troupes, costumes, etc. Entries tend mainly to be playwrights, specific plays, genres, and terminology. A useful feature is the inclusion of an appendix of some "Basic Documents in Dramatic Theory," twenty-four brief essays ranging from Aristotle to Dürrenmatt.-G.L.

Litto, Fredric M. American Dissertations on the Drama and the Theatre; a Bibliography. [Kent, Ohio]: Kent State Univ. Press, [1969]. 519p. \$12.50. (7176761).

A welcome addition to the growing list of bibliographies of dissertations in special subject fields, this volume brings together references to more than 4,500 doctoral dissertations "on subjects related to theatre and drama completed in all academic departments of American (the United States and Canada) universities."-Pref. The bibliography is arranged by "reference code" number (not alphabetically by author as might appear at first glance), and there are author, keyword-in-context, and subject indexes. Cutoff date is 1965. The compiler proposes to publish annual lists for the years since 1965 and, inasmuch as this is a computer-produced work, to bring out updated editions of the bibliography at five-year intervals.-E.S.

Stratman, Carl Joseph, ed. Restoration and 18th Century Theatre Research Bibliography, 1961-1968. Comp. by edmund A. Napieralski and Jean E. Westbrook. Troy, N.Y.: Whitson, 1969. 241p. $\$ 10.50$. (75-79626).

An annotated bibliography of 1,186 items, this is a cumulation of the seven annual lists from Restoration and 18th Century Theatre (formerly 17th and 18th Century Theatre Research) covering 1961 through 1967. It provides more extensive coverage for the subject than the corresponding sections of more general literary annual bibliographies currently published. Included are periodical articles, essays in collections, dissertations and books, the great majority of materials in English. Arrangement is by subject term (e.g., acting, prompt books) and names of dramatists, actors, etc., as subjects in one alphabet. The disadvantage of this dictionary arrangement is obvious when some sixty entries appear under the term "miscellaneous." There is no list of periodicals indexed, but citations are full. A list of subject headings used would have been helpful in lieu of the table of contents that a classed arrangement would have required. Running heads are lacking so that subject terms, although set in solid caps, are elusive. There is an author index.-R.K.

\section{Music}

Gerboth, Walter. An Index to Musical Festschriften and Similar Publications. New York: Norton, 1969. 188p. \$9.75. (68-12182).

Articles in Festschriften are very important in music scholarship, especially because a scholar often uses them to update or amend his research. Honorary studies, however, are often difficult to find and are seldom indexed. Professor Gerboth has compiled a very useful index and one that is easy to use. The work first appeared in a Festschrift for Gustave Reese (Aspects of Medieval and Renaissance Music. New York, 1966); it has now been expanded to include Festschriften published through 1967, earlier volumes previously omitted, music articles in nonmusical Festschriften, and works published in Slavic languages. In addition, any unpublished Festschrift which could be located was included.

The index is divided into three parts: (1) a list of the Festschriften; (2) a subject list of articles in these publications; and (3) an index by author and specific subject. Each article is listed only once in the second part, the preferred citation being under the historical period if at all appropriate. There are cross-references to other periods or individuals as needed. The compiler drew his bibliography from music bibliographies and from the catalogs of the New York Public Library, the Library of Congress, and the Columbia University Libraries. So, although no locations are indicated, the researcher can usually expect to find a given item in one of these three libraries.-E.M. 


\section{Foundations}

Directory of European Foundations. ${ }_{[}$Ed. 1] Ed. by Fondazione Giovanni Agnelli. Torino, 1969. 550p. $\$ 9$.

Foundation directories having recently appeared for Great Britain (Directory of Grant-making Trusts, 1968; Suppl. 2CA6), Australia (Directory of Philanthropic Trusts in Australia, 1968), and Latin America (Philanthropic Foundations in Latin America, 1968; Suppl. 2CA8), this new work brings us another step closer to worldwide coverage of organized philanthropic activities. Although it includes only 301 foundations of an estimated total of 250,000 in Europe today, the directory represents a high percentage of those which fall within its stated limits: those having annual expenditures of $\$ 5,000$ or more, or assets of at least $\$ 100,000$. Arrangement is alphabetical within the fifteen country sections; there are indexes of persons and of foundation names. Unfortunately no subject approach by field of activity has been provided.-E.S.

\section{Social Sciences}

Mason, John Brown. Research Resources: Annotated Guide to the Social Sciences. Santa Barbara, Calif.: ABC-Clio Press, 1968- v.1, International relations and recent history: indexes, abstracts and periodicals. 243p. $\$ 7.75$. (68-9685).

Professor Mason has undertaken to provide a guide to the masses of bibliographic material in international relations and recent history. This first volume deals with access to books, periodicals, and newspapers; the next volume will discuss official publications. The work begins with an annotated list of indexes and abstracts in all areas of the social sciences and history; then follows a list of important periodicals of interest to researchers in international relations and history. A further section lists materials giving bibliographic access to reference works, with special chapters on guides to reference books, bibliographies of bibliographies, and bibliographies devoted to individual topics. Then follow lists of special kinds of reference books, such as biographical dictionaries, encyclopedias and atlases, national and trade bibliographies, and guides to U.S. government publications. The work concludes with a section on the press. There are author and title indexes. For the student who will spend time studying this guide, it will be a valuable introduction to research resources in the fields indicated.-E.M.

Seidman, Joel Isaac. Communism in the United States; a Bibliography. Ithaca: Cornell Univ. Press, [1969]. 526p. \$17.50. (69-12427).

Although this bibliography is based on the 1955 Bibliography on the Communist Problem in the United States (Guide CI174), over half of its 7,000 items are not drawn from the earlier work. It attempts systematic coverage of the period from the inception of the Communist movement in the United States in 1919 to its decline in the late $1950 \mathrm{~s}$; material of unusual interest published before and after these years is included, however. Because the literature relating to the movement is so extensive, the author has had to set up strict criteria for inclusion. His title is somewhat misleading, for he emphasizes material by and about the official party and its members to the exclusion, for the most part, of writings of front organizations and on Communist theory. Both monographs and periodical articles (but not newspaper items) are included. Citations are accompanied by brief annotations which often give information about the author or the particular significance of the publication. The work might have been easier to use had it been arranged by topic instead of alphabetically by author, especially since the subject index is insufficiently detailed. It is basically a valuable list, however, selecting from a large and frequently evasive body of literature the more important and representative publications.-N.S.

Theodoratus, Robert J. Europe: A Selected Ethnographic Bibliography. New Haven: Human Relations Area Files, 1969. 543p. \$18.50 pa. (75-87851).

The absence of a general ethnographic bibliography is a lacuna this compilation 
seeks to fill. All of Europe is included except for the Caucasus and the Finno-Ugric and Turkic peoples; arrangement is by country, then by ethnic group. Emphasis is on the modern period, principally nineteenth and twentieth centuries. The work is admittedly uneven because standards of selection, high for countries about which there is a wealth of published material, dropped drastically for areas with scant published data "in order to provide a balanced coverage."-Pref. There is a list of journals cited, but no index.-R.K.

Vesenyi, Paul E. European Periodical Literature in the Social Sciences and the Humanities. Metuchen, N.J.: Scarecrow Press, 1969. 226p. \$5. (79-7052).

Recognizing an increasing need for ways to locate periodical articles in the social sciences and humanities, Vesenyi has made it his objective to list and analyze the growing number of current periodical indexing services published in Europe, thereby enabling research workers to try to catch up bibliographically with increased subject specialization. The indexes and abstracts, miscellaneous bibliographies, directories, and union lists which provide access to European periodical literature are here arranged by country of publication (from Albania to Yugoslavia) and there is a thematic index for approaching the lists. The index includes a section of "general bibliographies," which lists multidisciplinary works, and there is an appendix listing "name bibliographies" (i.e., bibliographies of individual persons) which include references to periodical literature. Each item is briefly described according to a predetermined format, with notes taking care of variations in individual tools.M.M.

\section{History and Area Studies}

Crowther, Peter A., comp. A Bibliography of Works in English on Early Russian History to 1800. Oxford: Blackwell; New York: Barnes \& Noble, 1969. 236p. $\$ 9.50$. (71-9351).

The compiler of this bibliography has attempted to provide a comprehensive listing in the fields of Russian general history, foreign relations, and social and eco- nomic history, but has added more selective sections on language and the arts. Both separately published materials and articles in periodicals are included. Arrangement is by broad topic, with an author and subject index. Few of the more than 2,000 entries are annotated, but the more important works are described briefly in the chapter introductions, and citations to reviews are given where possible. The work is intended as a companion to David M. Shapiro's A Select Bibliography of Works in English on Russian History, 1801-1917 (Oxford, 1962).-N.S.

\section{The Far East and Australasia, 1969-}

London: Europa, [1969- ]. £8. Annual.

Subtitle: A survey and directory of Asia and the Pacific.

Planned as an annual survey, this new work is designed "to provide a systematic directory of political and economic organization in each country, and to serve as an introduction to the problems that the region in general and each country in particular are encountering in developing viable economic, social and political structures."-Foreword. States and territories are discussed in four major units: South Asia, South East Asia, East Asia, and Australasia and the Pacific Islands. A general introduction to the religions, development problems, aid and investment, and major commodities is followed by chapters on regional cooperative organizations. The bulk of this latter material (as well as the statistical surveys of the individual countries which follow) is the same as that which appears in v.2 of Europa Year Book (Guide CI37). Also, the information on educational institutions and learned societies duplicates that given in the World of Learning (Guide CB69). However, introductory chapters on each nation's physical and social geography, history, and economy have been added, as have bibliographies. A useful reference section at the end of the volume includes a "Who's Who in the Far East and Australasia."J.S.

Horecky, Paul L., ed. East Central Europe; a Guide to Basic Publications. 
Chicago: Univ. of Chicago Press, [1969]. 956p. \$25.25. (70-79472).

Compiled by a team of scholars as one of the two bibliographies mandated by the survey made by the Subcommittee on East Central and Southeastern Europe of the American Council of Learned Societies and the Social Science Research Council, this important bibliographical guide to an area not previously covered will prove valuable as a study aid, research tool, and means of developing library resources. It "records basic books, periodicals, and, occasionally, articles of special pertinence, on the lands and peoples of Czechoslovakia, East Germany (including . . . the Lusatians and Polabians), Hungary and Poland" (Pref.), principally in the social sciences. Selection of materials was made on the basis of scholarly and informational merits and, although emphasis is on recent developments, much background material is included. Annotations are evaluative and descriptive.

The first chapter lists reference aids and the more general works; succeeding sections are devoted to individual countries with subdivisions for land, people, history, state, economics, society, intellectual history, and the organization of scientific research activities. Entries are serially numbered throughout and give author, title, translation of Slavic language title, imprint, and paging. There is an extensive author-title-subject index.-R.K.

Jelavich, Charles, ed. Language and Area Studies: East Central and Southeastern Europe; a Survey. Chicago: Univ. of Chicago Press, [1969]. 483p. \$11.50. (72-81222).

The purpose of this survey (undertaken by the Subcommittee on East Central and Southeastern Europe appointed by the Joint Committee on Slavic Studies of the American Council of Learned Societies and the Social Science Research Council) "is to indicate the strengths and weaknesses, the accomplishments and the failures in American training and scholarship, and to indicate the direction the participants in this project would like to see research and training in this field move in the future." -Pref. The area named in the title in- cludes Poland, Czechoslovakia, Hungary, Romania, Yugoslavia, Bulgaria, Albania, Greece and, where relevant, European Turkey and East Germany. Two chapters are devoted to graduate training and undergraduate instruction in the pertinent area studies. Then follow fifteen essays on as many social science and humanities disciplines (history, political science, literature, linguistics, etc.) which examine the state of American scholarship, give a brief account of its development, its recent achievements and present needs, suggestions for new areas of research, evaluation of graduate training and recommendations for its improvement and expansion. Chapters do not conform to a rigid pattern, but usually cover the topics mentioned. Librarians will appreciate the bibliographical character of many of the individual essays. - R.K.

\section{SCIENCE}

Akademiia Nauk SSSR. Institut Nauchnoi Informatsii. Mirovaia nauchnaia $i$ tekhnicheskaia literatura. Annotirovannyi spravochnik periodicheskikh $i$ prodolzhaiushchikhsia izdanii. Moskva, 1968- . (In progress) v.1, Astronomiia, geodeziia, matematika, mekhanika. 298p. 1r., $60 \mathrm{k}$.

Title also in English (World Scientific and Technical Literature; Annotated Index of Periodicals and Serials), German, French, and Spanish.

The first volume published in a projected seven-volume set which will eventually cover all branches of science, this international guide lists periodicals indexed in the Academy's series of abstract journals (Guide EA72). Titles are first listed in six separate alphabets: Cyrillic, Roman, Armenian, Georgian, Chinese and Japanese, and Korean. The main section, classed by subject, includes full bibliographic information, price, and the address where the journal may be obtained. A brief paragraph, in Russian, indicates more specifically the subject matter covered by the periodical, the language in which it appears, and the audience for whom it is intended. Official abbreviations and a geographic index are also included.-N.S. 